\title{
Comparing research performance of private universities in India with IITs, central universities and NITs
}

\author{
Sumit Kumar Banshal, Vivek Kumar Singh* and Philipp Mayr
}

During the last two decades the number of private universities in India has increased significantly. According to AISHE report of 2016, out of 799 universities in India, 277 are private universities, i.e. one out of every three universities in India is a private university. A significant proportion of colleges (about 78\%) are also privately managed, as they do not contribute much to research activities and hence are not included in this analysis. Private universities are now becoming a major component of the Indian higher education system. Some of the private universities are exclusively positioning and projecting themselves as universities for high quality research and innovation. A few of them are now well placed in the national-level NIRF ranking framework. It is in this context that this paper presents a comparative account of research performance of the 25 most productive private universities with the set of Indian Institutes of Technology (IITs), Central Universities (CUs) and National Institutes of Technology (NITs), all of which have a well-established environment and culture of research. A set-based comparison methodology is followed. The results show good performance of private universities in research, especially in terms of output and rate of growth of output. However, on quality and productivity per capita and per rupee spent, they have a long way to go to match the performance levels of well-established centrally funded higher education institutions of India. This study presents detailed scientometric assessment of some most productive private universities in India.

Keywords: Private universities, research performance, research in India, research policy.

THE higher education system in India comprises different kinds of institutions: universities, colleges and standalone institutions. According to the All India Survey on Higher Education (AISHE) for 2015-16 (ref. 1), there are 799 universities, 39,701 colleges and 11,923 stand-alone institutions. These institutions have different funding and management structures, with some established and managed by union government, some managed by state governments and others managed by private bodies. Out of 799 universities, 277 (about $35 \%$ of the total number of universities) are privately managed. Similarly, a large number of colleges (about $78 \%$ ) are also privately managed, though they are out of the scope of this study. The number of private universities has grown rapidly during the last two decades and many new private universities

Sumit Kumar Banshal is in the Department of Computer Science, South Asian University, New Delhi 110 021, India; Vivek Kumar Singh is in the Department of Computer Science, Banaras Hindu University, Varanasi 221005 , India; Philipp Mayr is in the GESIS Leibniz Institute of Social Sciences, Cologne, Germany.

*For correspondence. (e-mail: vivek@bhu.ac.in) are still coming up. For example, during 2010-11 there were 178 private universities ( 87 state private universities and 91 privately managed deemed universities). This number has grown to 287 private universities (197 state private universities and 90 privately managed deemed universities) in 2015-16. The private sector is thus becoming an important stakeholder in higher education system of the country.

A significant number of private universities offer professional courses in engineering, medicine, pharmacy, management, etc. Some of the relatively older private universities have also figured in different International Rankings of Universities under different categories. Some of them are also becoming preferred choices of students owing largely to their good infrastructure, teaching quality and employability prospects. Few private universities have made serious efforts in recruiting good teachers and promoting research. It is in this context that we tried to analyse the research performance of some of the wellknown private universities in India. Research publication data of the 40 most productive private universities for 2010-2016 are collected from Web of Science (WoS) and 
analysed computationally. Of the 40 private universities, we selected the 25 most productive private universities and compared their research performance with wellknown government universities and institutions, like Indian Institutes of Technology (IITs), Central Universities (CUs) and National Institutes of Technology (NITs). The main objective is to analyse the research performance of private universities and try to figure out if the private universities in India can be expected to match the research performance levels of well-established government institutions - both in terms of quantity and quality.

\section{Related work}

Most of the previous research efforts on assessing the research performance of Indian institutions focused on premier institutions like $\mathrm{IITs}^{2}$, IISERs ${ }^{3}, \mathrm{CUs}^{4,5}$, NITs ${ }^{6,7}$, etc. Some other notable initial works on Indian institutions analysed a group of them (usually a mix of institution types). One related previous study ${ }^{8}$ tried to identify top 30 Indian engineering and technological institutions according to their research performance in the time period 1999-2008. Later on Prathap ${ }^{9}$ benchmarked research performance of seven older IITs based on research output data from Web of Science (WoS) and Scopus. Recently, Prathap ${ }^{10}$ mapped the research performance of higher educational institutions in India by using SCImago Institutions Rankings (SIR) world reports of 2013, which in turn was based on the indexed data from Scopus for the period 2007-2011. Nishy et al. ${ }^{11}$ performed an impactCitation-Exergy (iCX) trajectory analysis of leading research institutions in India for some top performing institutions.

However, most of the studies did not exclusively focus on private universities. The only previous report with focus on private universities in India is by Prathap and Sriram $^{12}$. In this work, the authors selected seven mega private-funded institutions using the bibliometric and financial data from NIRF 2017 (ref. 13) and compared them with IISc, on both research excellence and socioeconomic performance. The authors have extended the approach originally used for the top 25 institutions in the engineering category according to NIRF 2017 (ref. 14). The study employed NIRF 2017 data of both bibliometric and financial sources for detailed analysis of the seven mega private universities ranking high in NIRF 2017. The results show that though these universities have the infrastructure for good quality research, they do not match the capital expenditure per faculty vis-à-vis institutions like IISc Bengaluru, in order to become attractive destinations for best faculty and researchers.

The present study, however, is different in its nature and purpose. It takes a set-based approach to compare research performance of 25 most productive private universities with sets of IIT, CU and NIT. The institution sets are compared as a group and research performance of individual institutions are not emphasized. The main aim is to find out whether the most productive private universities, taken collectively, are likely to produce more research output than well-established institutions in government sector and if they can emerge as new destinations of academic research. Some of the private universities in the set are very large universities, with multiple campuses, large number of faculty and modern infrastructure. It may be likely that in the time to come, owing to their modern infrastructure and better salaries, they may be able to attract good quality researchers, who can help these universities to match the research performance levels of well-known government-funded institutions.

\section{Data and methodology}

The publication data were collected from WoS during May-June 2017. Research publication records for 40 most productive private universities of India are collected for the period 2010-2016. In order to collect these data, institution-based search strings were generated from analytical results of Indian research output in WoS. All possible name variations for each of these 40 private universities were analysed and checked. For example, to search publication records for Satyabhama University, the search string of the form $\mathrm{CU}=$ (INDIA) AND $\mathrm{OG}=($ SATHYABAMA INST SCI TECHNOL $O R$ SATHYBAMA UNIV OR SATHYABAMA UNIV $O R$ SATHYABAMA UNIV CHENNAI), Indexes $=$ SCIEXPANDED, SSCI, A\&HCI, ESCI, TIMESPAN = 2010-2016, was used. There were name variations in the data indexed by WoS and hence manual checking for all possible name variations was necessary. This was also necessary because some private universities have either different campuses at different places or are registered as two independent universities in different states but with very similar names. We have included output from multiple campuses of a university as one institution only when they are recognized as one legal entity. This excludes universities established by the same private group as different independent entities in different states. For example, Manipal University has three campuses in three different places, all registered as independent universities and hence they are regarded as independent institutions. Publication records for each of the 40 private universities were downloaded and saved as independent CSV files. A total of 31,679 publications records were found indexed in WoS for the 40 private universities during the period 2010-2016. Out of this, 31,675 were unique records. These records correspond to all publication types and included cited references. Some other relevant data such as establishment year of the institution and annual budget were obtained from respective websites of the universities as well as relevant government sites. 
Since the research performance of private universities were to be compared with well-established government institutions, we have downloaded data for the same time window for the government-funded institution-sets. There were thus four different institution sets, for which data was downloaded. The first set was 25 most-productive private universities. Second set comprised set of all IITs. There are a total of 23 IITs in India. Out of this, some are very new (IIT Jammu, IIT Goa, IIT Bhilai and IIT Dharwad, established in 2016), with no significant research output. We could, therefore, obtain significant research publications records for 19 IITs only, for the period 2010-2016. A total of 51,159 publication records were found in WoS, with unique records being 49,420. Similarly, the third set comprised CUs. All the CUs which are under the purview of Ministry of Human Resource Development, Government of India are considered in the set. A few centrally funded institutions which are under the purview of other central ministries or with different purpose and nature have been excluded. As for example, the Indira Gandhi National Open University (IGNOU), New Delhi was excluded as it has a different nature and purpose. In the set of CU, some institutions are more than 100 years old (e.g. Banaras Hindu University), whereas some are established recently, 2009 (e.g. Central University of Rajasthan). There are thus 41 CUs of which we included 25 most productive Universities in the CU set. A total of 41,470 publications records are indexed in WoS for this set, with 41,314 being unique records.

The fourth set of institutions comprises NITs. There are now a total of 31 institutions recognized as NIT. Some of the NITs are quite old whereas several others are recently established. At least 10 institutions in the set are established after 2007. Research publication data is obtained for all NITs, with no significant records found for some very new NITs. A total of 16,714 publication records are found indexed in WoS, with 16,708 being unique records. We thought it is relevant to compare with the set of NITs since a good number of institutions in private universities set are primarily Engineering and Technology institutions.

The collected research publication records are analysed by writing programs in $\mathrm{R}$ language. Each research publication record in the data consisted of 66 fields. These fields included information like Paper Title (TI), Paper Type (PT), Authors (AU), Publication Year (PY), Citations (Z9), etc. The data are analysed computationally to compute standard scientometric indicators. Parameters of total papers (TP), total citations (TC), average citation per paper (ACPP) and $h$-index are obtained for all the four sets of institutions. Proportionate contribution of each of the sets in top $1 \%$ most-cited papers (referred to as $\mathrm{HiCP}$ ) from the set is computed as well. International collaboration pattern (ICP) of all the institution sets is also analysed. Finally, research publication records of all the four institution sets are analysed to measure their dis- ciplinary distribution. This is done by mapping each publication record to a broader discipline. Analytical results are presented in the following sections, coupled with different tables and figures.

\section{Research productivity and growth}

First parameter of analysis was the research productivity of different institution sets. Since the four sets have different number of institutes, only 25 institutions from all sets are considered for comparison, as described earlier. Among the four sets, IIT set has only 19 institutions as the 4 newer IITs do not have significant research output. For the other three sets, top 25 most productive institutes are selected. The number of publications for the four sets, namely private universities, IITs, CUs and NITs are found as 28,466, 51,159, 41,470 and 16,604 respectively. Table 1 presents these values for the four institution-sets. It can be seen that, in terms of cumulative output, IIT set accounts for highest number of research publications followed by $\mathrm{CU}$ and then private universities. The relative growth rate (RGR) for all the institution-sets has also been computed. It is interesting to observe that private universities institution-set has a higher growth rate compared to IIT set. The RGR of private universities set is higher for all the years compared to CU set as well.

The TP value for each of the four sets is plotted along with predictions for TP values of all the four institutionsets for the coming years through curve fitting. For this purpose, curve fitting feature provided in MS Excel is used. Due to large and varied data, polynomial curve fitting is found suitable. The polynomials are generated based on the present data to predict future. The plots are shown in Figure 1. The $R^{2}$ (coefficient of determination for regression line accuracy) value is quite high in all the cases $(>0.9)$, which is near to 1 . Therefore, it can be said that the polynomials are well fitted to data and should generate a good prediction. It can be observed that IIT set shows signs of continuing on the top in the years to come. The private universities set is likely to cross the CU set in terms of TP values in the coming years. The CU set shows a slow growing curve, whereas NIT set may be able to match the TP levels of CU in future. The prediction curves present an interesting pattern about private universities set, which shows that private universities are likely to be the second largest contributors to Indian research output after IIT set.

To understand the contribution of each set in Indian set, the proportionate shares of these institutes are plotted in Figure 2. As on the date of data download, the total output of India for the period 2010-2016 is 458,792. We have divided the TP values of each institution set to understand their proportionate contribution to India's total research output. It is observed that the IITs are the leading institution-set, with $11.2 \%$ contribution to total Indian 
GENERAL ARTICLES

Table 1. List of 25 most productive institutions in each set with publication count

\begin{tabular}{|c|c|c|c|c|c|c|c|}
\hline \multicolumn{2}{|l|}{ PVT } & \multicolumn{2}{|l|}{ IIT } & \multicolumn{2}{|l|}{$\mathrm{CU}$} & \multicolumn{2}{|l|}{ NIT } \\
\hline Institution & $\mathrm{TP}$ & Institution & $\mathrm{TP}$ & Institution & ТP & Institution & TP \\
\hline Manipal University & 4018 & IIT Kharagpur & 9208 & University of Delhi & 8327 & $\begin{array}{l}\text { National Institute of } \\
\text { Technology Rourkela }\end{array}$ & 2185 \\
\hline $\begin{array}{l}\text { Vellore Institute of } \\
\text { Technology }\end{array}$ & 3570 & IIT Bombay & 7485 & $\begin{array}{l}\text { Banaras Hindu } \\
\text { University }\end{array}$ & 8054 & $\begin{array}{l}\text { National Institute of } \\
\text { Technology Tiruchirappalli }\end{array}$ & 2072 \\
\hline Thapar University & 2270 & IIT Delhi & 7172 & $\begin{array}{l}\text { Aligarh Muslim } \\
\text { University }\end{array}$ & 4307 & $\begin{array}{l}\text { Sardar Vallabhbhai National } \\
\text { Institute of Technology }\end{array}$ & 1178 \\
\hline BITS Pilani & 2254 & IIT Madras & 7122 & $\begin{array}{l}\text { University of } \\
\text { Hyderabad }\end{array}$ & 3795 & $\begin{array}{l}\text { National Institute of } \\
\text { Technology Durgapur }\end{array}$ & 1146 \\
\hline Jamia Hamdard & 1950 & IIT Kanpur & 5957 & $\begin{array}{l}\text { Jawaharlal Nehru } \\
\text { University }\end{array}$ & 3012 & $\begin{array}{l}\text { National Institute of } \\
\text { Technology Karnataka }\end{array}$ & 1106 \\
\hline $\begin{array}{l}\text { S.R.M. Institute of Science } \\
\text { and Technology }\end{array}$ & 1809 & IIT Roorkee & 5871 & Jamia Milia Islamia & 2175 & $\begin{array}{l}\text { Motilal Nehru National } \\
\text { Institute of Technology }\end{array}$ & 929 \\
\hline Amrita Vidyapith & 1639 & IIT Guwahati & 2880 & $\begin{array}{c}\text { University of } \\
\text { Allahabad }\end{array}$ & 1845 & $\begin{array}{l}\text { National Institute of } \\
\text { Technology Warangal }\end{array}$ & 878 \\
\hline BIT MESRA & 1291 & IIT Hyderabad & 1052 & $\begin{array}{l}\text { Pondicherry } \\
\text { University }\end{array}$ & 1766 & $\begin{array}{c}\text { Ambedkar National Institute } \\
\text { of Technology Jalandhar }\end{array}$ & 811 \\
\hline Amity University & 1004 & IIT Indore & 932 & Tezpur University & 1655 & $\begin{array}{l}\text { National Institute of } \\
\text { Technology Calicut }\end{array}$ & 805 \\
\hline $\begin{array}{l}\text { Jaypee Institute of } \\
\text { Information Technology }\end{array}$ & 944 & $\begin{array}{l}\text { IIT (ISM) } \\
\text { Dhanbad }\end{array}$ & 789 & $\begin{array}{l}\text { Visva Bharati } \\
\text { University }\end{array}$ & 1601 & $\begin{array}{l}\text { National Institute of } \\
\text { Technology Kurukshetra }\end{array}$ & 792 \\
\hline $\begin{array}{l}\text { Siksha 'O' Anusandhan } \\
\text { University }\end{array}$ & 934 & IIT Bhubaneswar & 703 & $\begin{array}{l}\text { North Eastern } \\
\text { Hill University }\end{array}$ & 923 & $\begin{array}{l}\text { Visvesvaraya National } \\
\text { Institute of Technology } \\
\text { Nagpur }\end{array}$ & 727 \\
\hline Bharati Vidyapeeth & 905 & IIT Mandi & 485 & Assam University & 800 & $\begin{array}{l}\text { National Institute of } \\
\text { Technology Hamirpur }\end{array}$ & 702 \\
\hline Sri Ramachandra University & 659 & IIT Ropar & 454 & $\begin{array}{l}\text { Guru Ghasidas } \\
\text { University }\end{array}$ & 432 & $\begin{array}{l}\text { Malaviya National Institute } \\
\text { of Technology }\end{array}$ & 665 \\
\hline GITAM Institute & 587 & IIT Gandhinagar & 422 & Manipur University & 415 & $\begin{array}{l}\text { National Institute of } \\
\text { Technology Bhopal }\end{array}$ & 563 \\
\hline $\begin{array}{l}\text { Sathyabama Institute } \\
\text { of Science }\end{array}$ & 536 & IIT Patna & 256 & $\begin{array}{l}\text { Babasaheb Bhimrao } \\
\text { Ambedkar } \\
\text { University }\end{array}$ & 403 & $\begin{array}{l}\text { National Institute of } \\
\text { Technology Silchar }\end{array}$ & 449 \\
\hline $\begin{array}{l}\text { Jagadguru Sri } \\
\text { Shivarathreeswara } \\
\text { University }\end{array}$ & 506 & IIT Jodhpur & 231 & Mizoram University & 344 & $\begin{array}{l}\text { National Institute of } \\
\text { Technology Agartala }\end{array}$ & 418 \\
\hline Dr DY Patil University & 501 & IIT Varanasi & 131 & Tripura University & 282 & $\begin{array}{l}\text { National Institute of } \\
\text { Technology Raipur }\end{array}$ & 366 \\
\hline $\begin{array}{l}\text { KLE Academy of Higher } \\
\text { Education and Research }\end{array}$ & 496 & IIT Palakkad & 6 & $\begin{array}{l}\text { Central University } \\
\text { of Rajasthan }\end{array}$ & 276 & $\begin{array}{l}\text { National Institute of } \\
\text { Technology Srinagar }\end{array}$ & 178 \\
\hline $\begin{array}{l}\text { Kalasalingam Academy of } \\
\text { Research and Higher } \\
\text { Education }\end{array}$ & 419 & IIT Tirupati & 3 & $\begin{array}{l}\text { Central University } \\
\text { of Punjab }\end{array}$ & 190 & $\begin{array}{l}\text { National Institute of } \\
\text { Technology Jamshedpur }\end{array}$ & 154 \\
\hline ISF Coll Pharm & 409 & IIT Jammu & - & $\begin{array}{l}\text { Central University } \\
\text { of Jharkhand }\end{array}$ & 167 & $\begin{array}{l}\text { National Institute of } \\
\text { Technology Uttarakhand }\end{array}$ & 133 \\
\hline Nirma University & 409 & IIT Goa & - & $\begin{array}{l}\text { Central University } \\
\text { of Gujarat }\end{array}$ & 161 & $\begin{array}{l}\text { National Institute of } \\
\text { Technology Patna }\end{array}$ & 129 \\
\hline $\begin{array}{l}\text { Lovely Professional } \\
\text { University }\end{array}$ & 407 & IIT Bhilai & - & $\begin{array}{l}\text { Central University } \\
\text { of Kerala }\end{array}$ & 161 & $\begin{array}{l}\text { National Institute of } \\
\text { Technology Meghalaya }\end{array}$ & 98 \\
\hline $\begin{array}{l}\text { Maharishi Markandeshwar } \\
\text { University }\end{array}$ & 328 & IIT Dharwad & - & $\begin{array}{l}\text { Central University of } \\
\text { Tamil Nadu }\end{array}$ & 148 & $\begin{array}{l}\text { National Institute of } \\
\text { Technology Manipur }\end{array}$ & 44 \\
\hline $\begin{array}{l}\text { Sri Sathya Sai Institute of } \\
\text { Higher Learning }\end{array}$ & 318 & - & - & $\begin{array}{l}\text { Rajiv Gandhi } \\
\text { University }\end{array}$ & 139 & $\begin{array}{l}\text { National Institute of } \\
\text { Technology Delhi }\end{array}$ & 42 \\
\hline PES University & 303 & - & - & Sikkim University & 92 & $\begin{array}{l}\text { National Institute of } \\
\text { Technology Puducherry }\end{array}$ & 34 \\
\hline Total & 28,466 & Total & 51,159 & Total & 41,470 & Total & 16,604 \\
\hline
\end{tabular}

PVT, Private universities; IIT, Indian Institutes of Technology; CU, Central universities; NIT, National Institutes of Technology, TP, Total papers.

research, whereas CUs contribute $9 \%$ to the total Indian research output. The contribution of private universities set is $6.2 \%$, which is higher compared to NITs, which have proportionate contribution of $3.6 \%$. The four sets of institutions taken together, contribute about $30 \%$ to the total research output from India. Taking into account the fact 


\section{GENERAL ARTICLES}

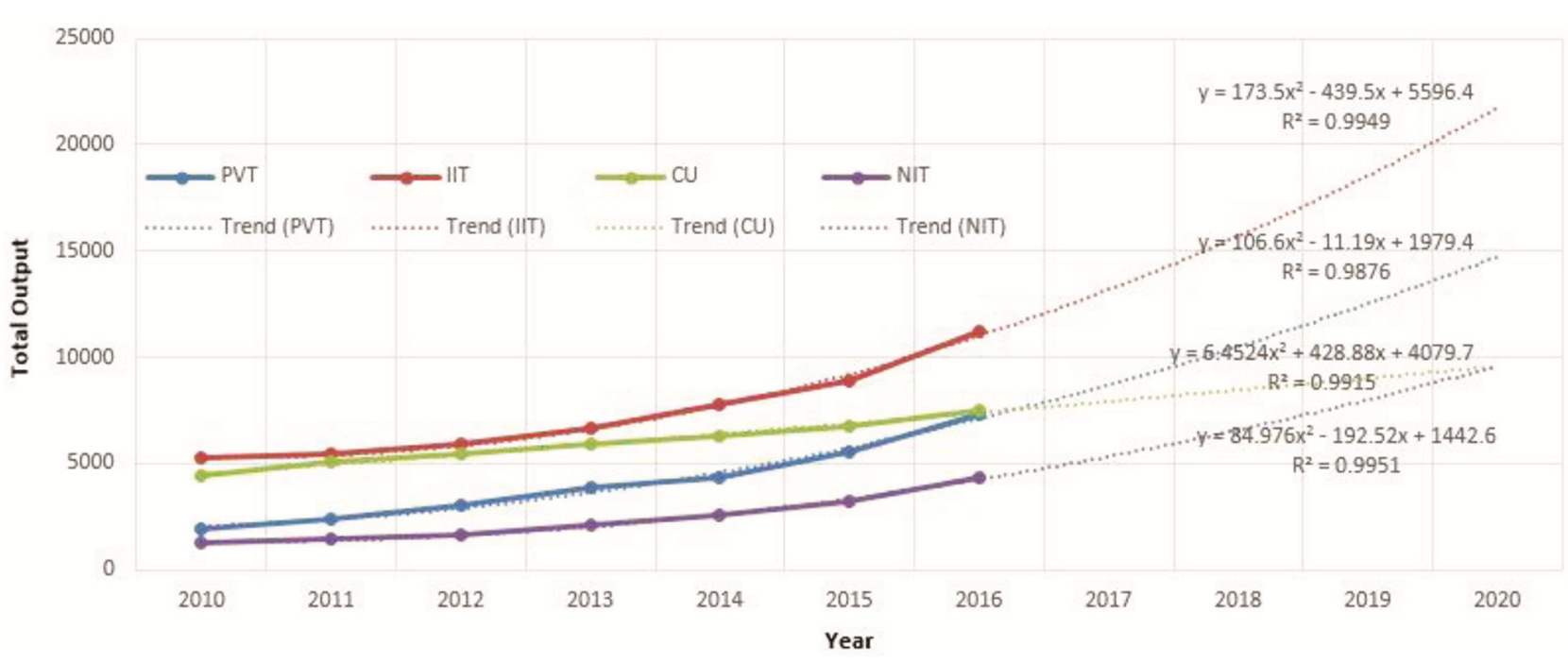

Figure 1. Total publications plotted for different institution-sets and output growth predictions.

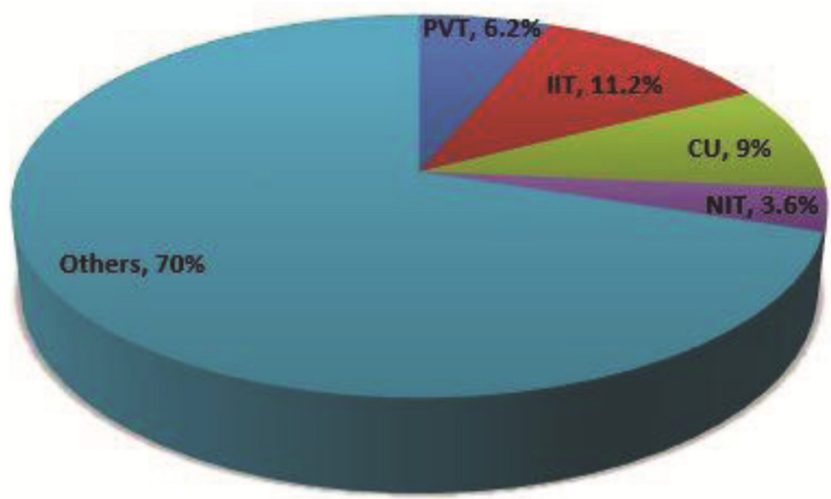

Figure 2. Proportionate share of each institution-set in total research output from India (2010-2016).

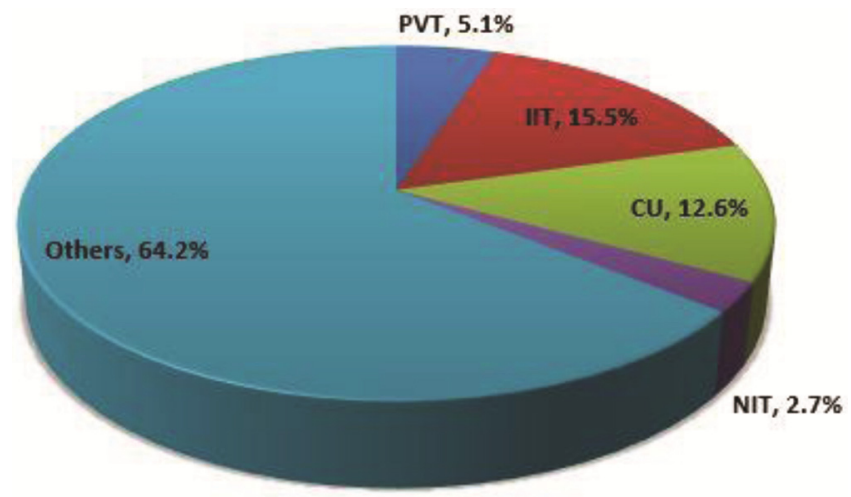

Figure 3. Proportionate contribution of each institution-set to top $1 \%$ most cited papers from India (2010-2016).

that these sets comprise 98 institutions in total, which is only about $12 \%$ of total number of Indian universities, their contribution to total Indian research output is significantly good.

\section{Quality of research}

In addition to analysing details of quantity of research output, it is important to measure the quality of the publications. Citation is the most widely used indicator for the purpose. The value of TC is directly available from the data. We have used the TC data and calculated ACPP and $h$-index for all the four institution-sets for each year. Table 2 presents these indicators for each of the four institution-sets. It can be observed that IIT set has the highest number of citations as well as the highest average $h$-index. This is followed by CU and then private universities. Taking into account the fact that private universities set has a good number of papers in the recent period, it can be expected that private universities will gain higher number of citations in the time to come, as the citation window size gets bigger.

We have also calculated the top $1 \%$ most cited papers of India during the 2010-2016 period. These top 1\% most cited papers (total 4588 papers) are referred to as highly cited papers (HiCP). We identified proportionate contribution of each of the four institution sets to this HiCP set. Figure 3 presents these values. The total contribution of all the four institution-sets is about $36 \%$ to the HiCP of India for the period. It is interesting to note that $12 \%$ of the total number of Indian universities accumulate about $36 \%$ of total HiCP instances. Among the four sets, IITs are in the top position with $15.5 \%$ contribution to HiCP, followed by CUs with $12.6 \%$. The private universities set lags here with $5.1 \%$ papers only in $\mathrm{HiCP}$ set, but it is almost double the NITs contribution of $2.7 \%$.

\section{International collaboration}

It is often stated that internationally collaborated research work gets higher visibility and hence has higher chances 


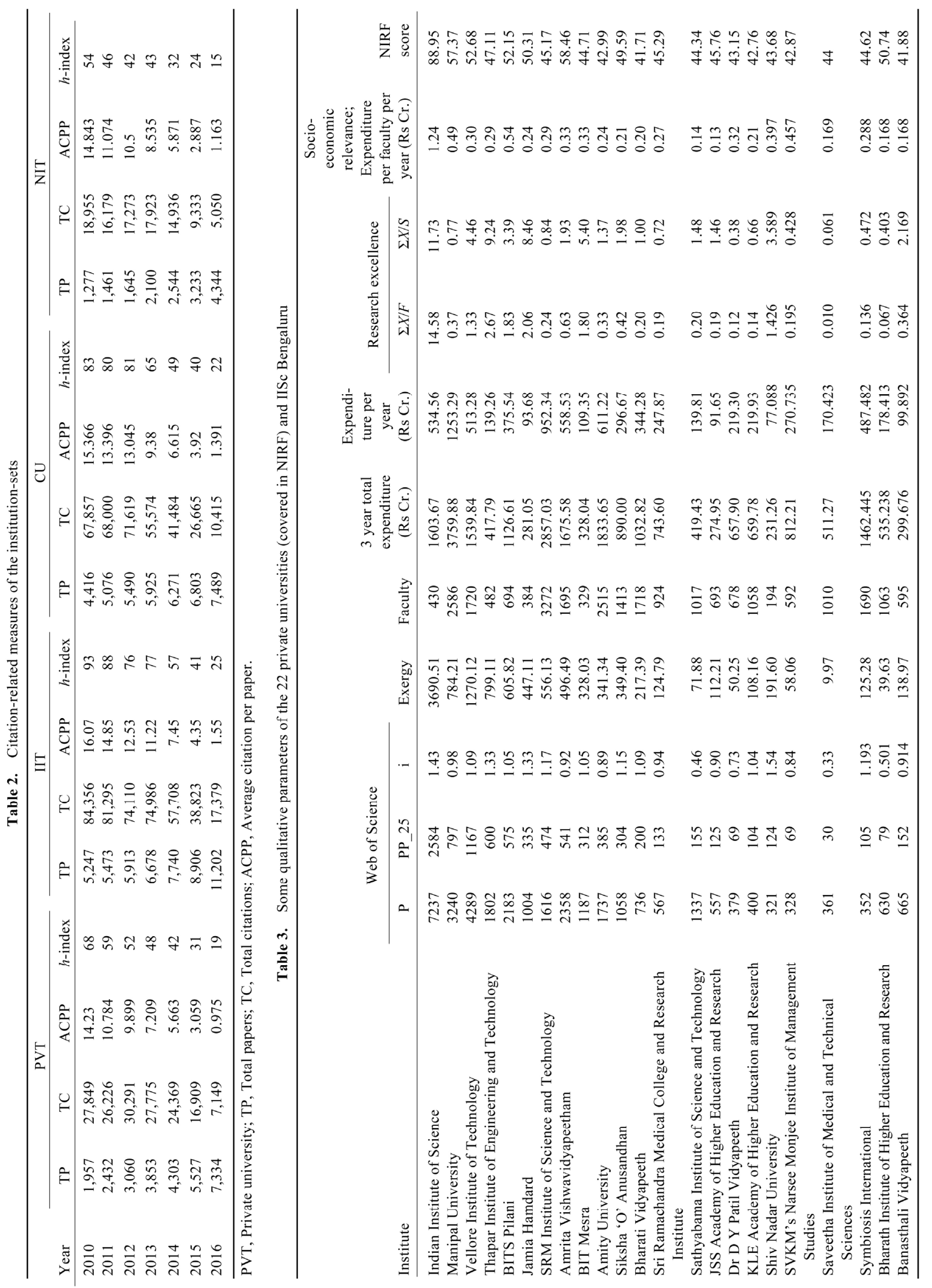


of citations. We have, therefore, identified the international collaboration pattern (ICP) for all the four institution sets. Figure 4 shows the year-wise ICP distribution of all the four sets of institutes. The proportion of ICP instances varies from about $25 \%$ for IITs to $15 \%$ for NITs. The CU set has ICP instance as $24.1 \%$ and the private universities set is close with ICP proportion of $21 \%$. There is a small decline in the recent years in three sets. In the private universities set a steep increase is noticed in 2014, which then hovers around a slightly smaller value during next two years. ICP instances of NITs are almost consistent to a $15 \%$ level throughout. Private university set has a significant amount of ICP instances. This shows that they have reasonable collaborations at international level.

\section{Discipline-wise distribution of research output}

In addition to analysing the quantity and quality indicators for the four sets, we also wanted to see what are the major disciplines in which the four institution-sets publish. It would be interesting to see if all the four institution-sets have similar disciplinary distribution or it varies across institution types. In order to see disciplinary distribution in published research output of all the four institution-sets, we have categorized each publication record for each set into one of the 14 disciplinary categories. These categories are: Agriculture (AGR), Art and Humanities (AH), Biology (BIO), Chemistry (CHEM), Engineering (ENG), Environment Science (ENV), Geology (GEO), Information Sciences (INF), Material Science (MTR), Mathematics (MAT), Medical Science (MED), Multidisciplinary (MUL), Physics (PHY) and Social Science (SS). The categorization is based on a previous work by Rupika et al. ${ }^{14}$. Figure 5 presents the spider charts (also known as Radar diagrams) of disciplinary distribution of research outputs of all the four institution-sets. Interestingly, different institution-sets have different number of papers in different disciplines. The private universities set has the highest number of papers

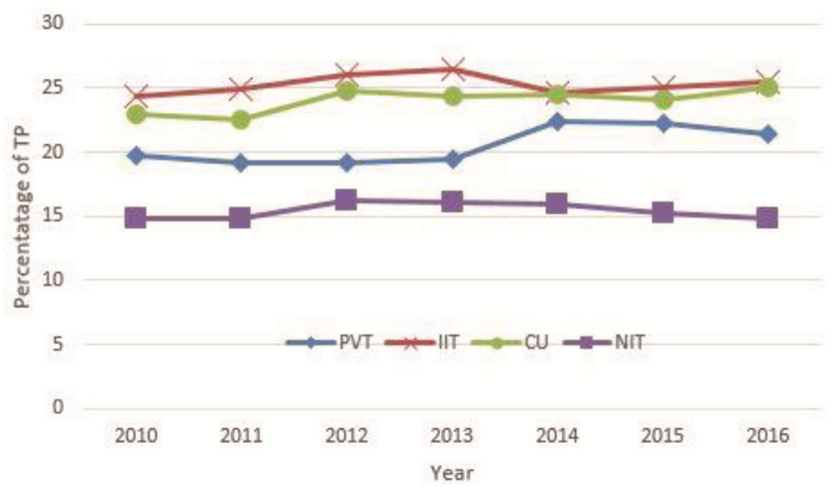

Figure 4. ICP proportion of all institution-sets plotted year-wise. in Medical Sciences. This is followed by Chemistry and Material Science. The IIT set has the highest number of publications in Physics followed by Engineering and then Material Science. The CU set has the highest number of publications in Chemistry, followed by Physics and then Biology. The NIT set has the highest number of publications in Engineering, followed by Physics and Material Science. Thus, there is clearly identifiable difference in disciplinary distribution of research papers of all the four institution-sets.

\section{Quality, productivity per capita and expenditure aspects in private universities}

To further compare the relative performance of private universities set, with other well-established institutions, we tried to look at productivity versus expenditure aspects of the institution-sets by looking at data from NIRF. To start with, we searched how many of these 40 institutions are present in NIRF. It was found that only 22 out of the 40 most productive institutions in private universities set are found in NIRF ranking. Therefore, we collected scores as well as faculty stats for these 22 institutions from NIRF. Along with these 22 universities, we also collected data for IISc Bengaluru to use as a reference benchmark exergy values of these institutes which are computed based on their research output and expenditure values. Table 3 presents the values computed for the 22 private universities along with values for IISc. It is observed that, there is a wide difference of NIRF scores between IISc and private universities, which is understandable from the expenditure per faculty per year. In IISc, the expenditure per faculty is 1.24 crores per year which is more than double of top performing private universities (Manipal university: 0.48 crore per year). Among the private universities, the most expenditure is done by BITS Pilani. When we look at exergy values, it is found highest for VIT (1270) as compared to value of 3690 for IISc. These values indicate that the private universities have a long way to go to match the funding level of top performing Government institutions like IISc, in order to achieve comparable research performance. These results are also congruent to findings of Prathap ${ }^{15}$.

\section{Indicator values for the $\mathbf{4 0}$ most productive private universities}

Since the main focus of this paper is on private universities, we thought to include relevant data for some more private universities. We have computed indicator values for the 40 most productive private universities that are part of our research data. The idea is to provide a detailed look at indicator values of other private universities as well. For each university, we have identified details of TP, TC, ACPP, ICP, $h$-index and contributions to Indian 
GENERAL ARTICLES

Table 4. Relevant statistics of the 40 most productive private universities (including 22 covered in NIRF)

\begin{tabular}{|c|c|c|c|c|c|c|c|c|}
\hline Institution name & Location & $\begin{array}{l}\text { Establishment } \\
\text { year }\end{array}$ & $\mathrm{TP}$ & $\mathrm{TC}$ & ACPP & ICP & $h$-index & $\begin{array}{l}\text { HiCP } \\
\text { contribution }\end{array}$ \\
\hline Manipal University & Manipal, Karnataka & 1956 & 4018 & 14020 & 3.49 & 812 & 36 & 5 \\
\hline Vellore Institute of Technology & Vellore, Tamil Nadu & 1984 & 3570 & 15542 & 4.35 & 729 & 37 & 14 \\
\hline Thapar University & Patiala, Punjab & 1956 & 2270 & 11993 & 5.28 & 320 & 36 & 9 \\
\hline BITS Pilani & Pilani, Rajasthan & 1964 & 2254 & 18658 & 8.28 & 649 & 49 & 27 \\
\hline Jamia Hamdard & New Delhi, Delhi & 1989 & 1950 & 15588 & 7.99 & 443 & 45 & 20 \\
\hline $\begin{array}{l}\text { S.R.M. Institute of Science and } \\
\text { Technology }\end{array}$ & Chennai, Tamil Nadu & 1985 & 1809 & 11869 & 6.56 & 457 & 41 & 23 \\
\hline Amrita Vishwavidyapeetham & Coimbatore, Tamil Nadu & 2003 & 1639 & 16221 & 9.9 & 458 & 55 & 46 \\
\hline BIT MESRA & Ranchi, Jharkhand & 1955 & 1291 & 7865 & 6.09 & 273 & 36 & 8 \\
\hline Amity University & Noida, Uttar Pradesh & 1995 & 1004 & 4318 & 4.3 & 293 & 25 & 8 \\
\hline $\begin{array}{l}\text { Jaypee Institute of Information } \\
\text { Technology }\end{array}$ & Noida, Uttar Pradesh & 2001 & 944 & 5645 & 5.98 & 125 & 29 & 6 \\
\hline Siksha 'O' Anusandhan University & Bhubaneswar, Odisha & 1996 & 934 & 4640 & 4.97 & 94 & 28 & 3 \\
\hline Bharati Vidyapeeth & Pune, Maharashtra & 1964 & 905 & 5432 & 6 & 159 & 31 & 10 \\
\hline Sri Ramachandra University & Chennai, Tamil Nadu & 1985 & 659 & 6314 & 9.58 & 137 & 25 & 8 \\
\hline GITAM Institute & Visakhapatnam, Andhra Pradesh & 1980 & 587 & 2043 & 3.48 & 86 & 20 & 3 \\
\hline Sathyabama Institute of Science & Chennai, Tamil Nadu & 1987 & 536 & 2245 & 4.19 & 56 & 21 & 2 \\
\hline $\begin{array}{l}\text { Jagadguru Sri Shivarathreeswara } \\
\text { University }\end{array}$ & Mysuru, Karnataka & 2008 & 506 & 1125 & 2.22 & 49 & 14 & 0 \\
\hline Dr DY Patil University & Pune, Maharashtra & 2004 & 501 & 2169 & 4.33 & 157 & 20 & 8 \\
\hline $\begin{array}{l}\text { KLE Academy of Higher } \\
\text { Education and Research }\end{array}$ & Belagavi, Karnataka & 1979 & 496 & 1690 & 3.41 & 103 & 17 & 1 \\
\hline $\begin{array}{l}\text { Kalasalingam Academy of } \\
\text { Research and Higher } \\
\text { Education }\end{array}$ & Srivilliputtur, Tamil Nadu & 1984 & 419 & 3557 & 8.49 & 157 & 29 & 11 \\
\hline ISF College of Pharmacy & Moga, Punjab & NA & 409 & 3731 & 9.12 & 85 & 26 & 8 \\
\hline Nirma University & Ahmedabad, Gujarat & 2003 & 409 & 2571 & 6.29 & 45 & 21 & 4 \\
\hline Lovely Professional University & Jalandhar, Punjab & 2005 & 407 & 1948 & 4.79 & 84 & 18 & 6 \\
\hline $\begin{array}{l}\text { Maharishi Markandeshwar } \\
\text { University }\end{array}$ & Ambala, Haryana & 1993 & 328 & 1342 & 4.09 & 47 & 16 & 1 \\
\hline $\begin{array}{l}\text { Sri Sathya Sai Institute of Higher } \\
\text { Learning }\end{array}$ & Anantapur, Andhra Pradesh & 1981 & 318 & 1777 & 5.59 & 93 & 22 & 1 \\
\hline PES University & Bengaluru, Karnataka & 1972 & 303 & 1442 & 4.76 & 38 & 18 & 1 \\
\hline Sharda University & Greater Noida, Uttar Pradesh & 2009 & 300 & 1956 & 6.52 & 118 & 21 & 4 \\
\hline Yenepoya University & Mangaluru, Karnataka & 2008 & 292 & 587 & 2.01 & 68 & 10 & 0 \\
\hline Shiv Nadar University & Chithera, Uttar Pradesh & 2011 & 289 & 1589 & 5.5 & 112 & 19 & 2 \\
\hline $\begin{array}{l}\text { Shoolini University of } \\
\text { Biotechnology and } \\
\text { Management Sciences }\end{array}$ & Solan, Himachal Pradesh & 2009 & 282 & 2084 & 7.39 & 113 & 23 & 1 \\
\hline $\begin{array}{l}\text { Narsee Monjee Institute of } \\
\text { Management Studies }\end{array}$ & Mumbai, Maharashtra & 1981 & 275 & 1101 & 4 & 41 & 16 & 0 \\
\hline $\begin{array}{l}\text { Saveetha Institute of Medical } \\
\text { and Technical Sciences }\end{array}$ & Chennai, Tamil Nadu & 2005 & 253 & 1033 & 4.08 & 53 & 17 & 0 \\
\hline BS Abdur Rahman University & Chennai, Tamil Nadu & 1984 & 240 & 1207 & 5.03 & 40 & 18 & 0 \\
\hline NITTE University & Mangaluru, Karnataka & 2008 & 234 & 439 & 1.88 & 43 & 10 & 0 \\
\hline $\begin{array}{l}\text { Pandit Deendayal Petroleum } \\
\text { University }\end{array}$ & Gandhinagar, Gujarat & 2007 & 176 & 957 & 5.44 & 30 & 15 & 0 \\
\hline $\begin{array}{l}\text { Noorul Islam Centre for Higher } \\
\text { Education }\end{array}$ & Kanyakumari, Tamil Nadu & 1989 & 173 & 752 & 4.35 & 30 & 15 & 0 \\
\hline Symbiosis International University & Pune, Maharashtra & 2002 & 163 & 420 & 2.58 & 44 & 9 & 0 \\
\hline Bharat Institute & Chennai, Tamil Nadu & 1984 & 141 & 597 & 4.23 & 40 & 11 & 0 \\
\hline The Northcap University & Gurgaon, Haryana & 1996 & 137 & 570 & 4.16 & 36 & 14 & 0 \\
\hline $\begin{array}{l}\text { Manav Rachna International } \\
\text { University }\end{array}$ & Faridabad, Haryana & 1997 & 133 & 773 & 5.81 & 27 & 13 & 3 \\
\hline Banasthali Vidyapeeth & Banasthali, Rajasthan & 1935 & 125 & 655 & 5.24 & 24 & 14 & 1 \\
\hline
\end{tabular}

TP, Total papers; TC, Total citations; ACPP, Average citation per paper; ICP, International collaboration pattern; HiCP, Highly cited papers.

HiCP. Table 4 presents indicator values for all the 40 private universities. It can be observed that Manipal University has highest number of publications followed by
Vellore Institute of Technology (3570), Thapar University (2270) and BITS Pilani (2254). In terms of total citations, Amrita Vishwavidyapeetham has highest number 


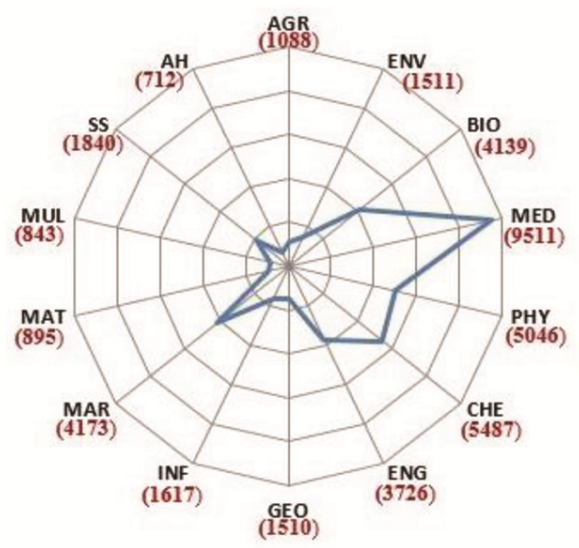

Discipline Wise Distribution of PVT

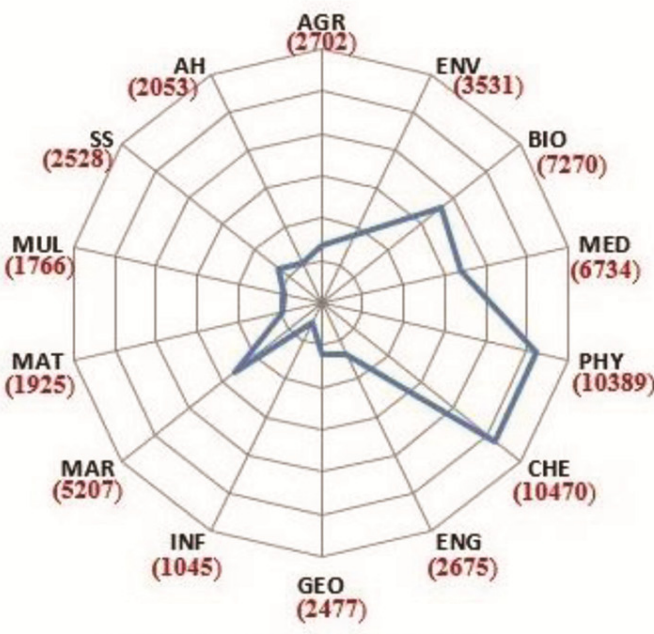

Disciplinewise Distribution of CU

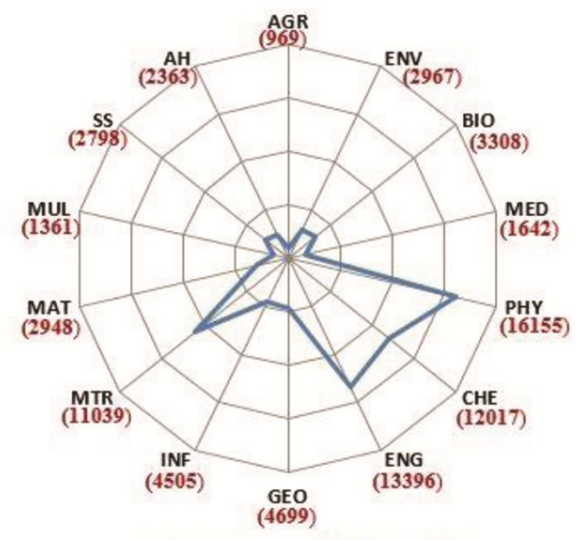

Discipline Wise Distribution of IIT

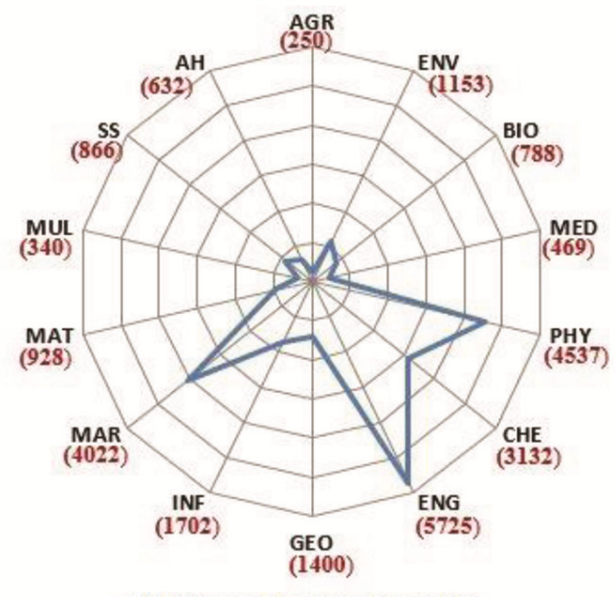

Disciplinewise Distribution of NIT

Figure 5. Discipline-wise distribution of institution-sets (2010-16).

$(16,221)$ followed by Jamia Hamdard $(15,588)$ and Vellore Institute of Technology $(15,542)$. Amrita Vishwavidyapeetham also has the highest $h$-index (55) followed by BITS Pilani ( $h$-index of 49 ) and Jamia Hamdard ( $h$ index of 45). In terms of international collaboration, Manipal University has highest amount of ICP instances (812) followed by Vellore Institute of Technology (729) and BITS Pilani (649). In terms of contribution to HiCP from India, Amrita Vishwavidyapeetham out numbered every other with 46 papers in the set, with BITS Pilani (27) at the second place. Some of these top performing universities are multi-campus mega universities under one university entity and hence have a size-related advantage over other institutions (private or government).

\section{Conclusion}

We have presented a set-theoretic comparison of 25 most-productive private universities with set of 23 IITs, 25 CUs and 25 NITs. Publication data from WoS were used for computing various performance indicators. The institution-sets were analysed based on productivity, citations, $h$-index and ICP parameters. Disciplinary variation of publications in the four institution sets is also observed. It is interesting to observe that private universities show a significant growth in the research output during the recent years. Given this rate of growth, they may surpass the CUs in terms of research output in the years to come. Private universities, however, lag a bit on citationrelated metric, though they are ahead of NITs on this. They also seem to perform well on international collaboration. Owing to their size-related advantage, some of the private universities have impressive research output and also good number of citations as well as international collaboration. Some of the multi-campus mega private universities are likely to make major gains in research output and quality parameters as well. This trend is an indicator of evolution of a new kind of universities in India, which are privately managed and are capable of maintaining good infrastructure and reasonably good-sized competent faculty. Private universities, however, have a long way to go to match the funding levels of top performing 
Government institutions, particularly on funds for research and innovation activities and research support to faculty members.

1. All India Survey on Higher Education (2015-16), Department of Higher Education, Ministry of Human Resource Development, Govt of India; http://mhrd.gov.in/sites/upload_files/mhrd/files/ statistics-new/AISHE2015-16.pdf

2. Banshal, S. K., Singh, V. K., Basu, A. and Muhuri, P. K., Research performance of Indian Institutes of Technology. Curr. Sci., 2017, 112(5), 923-932.

3. Solanki, T., Uddin, A. and Singh, V. K., Research competitiveness of Indian institutes of science education and research. Curr. Sci., 2016, 110(3), 307.

4. Marisha, Banshal, S. K. and Singh, V. K., Research performance of central universities in India. Curr. Sci., 2017, 112(11), 21982208.

5. Basu, A., Banshal, S. K., Singhal, K. and Singh, V. K., Designing a composite index for research performance evaluation at the national or regional level: ranking Central Universities in India. Scientometrics, 2016, 107(3), 1171-1193.

6. Bala, A. and Kumari, S., Research performance of National Institutes of Technology (NITs) of India during 2001-2010: a bibliometric analysis. SRELS J. Inf. Manage., 2013, 50(5), 555-572.

7. Banshal, S. K., Solanki, T. and Singh, V. K., Research performance of National Institutes of Technology. Curr. Sci., 2018, 115(11), 2025-2036.

8. Prathap, G. and Gupta, B. M., Ranking of Indian engineering and technological institutes for their research performance during 1999-2008. Curr. Sci., 2009, 97(3), 304-306.
9. Prathap, G., Benchmarking research performance of the IITs using 'Web of Science' and 'Scopus' bibliometric databases. Curr. Sci., 2013, 105(8), 1134-1138.

10. Prathap, G., The performance of research-intensive higher educational institutions in India. Curr. Sci., 2014, 107(3), 389-396.

11. Nishy, P., Panwar, Y., Prasad, S., Mandal, G. K. and Prathap, G., An impact-Citations Exergy (iCX) trajectory analysis of leading research institutions in India. Scientometrics, 2012, 91(1), 245251.

12. Prathap, G. and Sriram, P., Mega private universities in India: prospects and promise for world-class performance. Curr. Sci., 2017, 113(11), 2165-2167.

13. www.nirfindia.org

14. Rupika, Uddin, A. and Singh, V. K., Measuring the universityindustry-government collaboration in Indian research output. Curr. Sci., 2016, 110(10), 1904-1909.

15. Prathap, G., Making scientometric and economic sense out of NIRF 2017 data. Curr. Sci., 2017, 113(7), 1420-1423.

ACKNOWLEDGEMENTS. We acknowledge the support provided by the Indo-German Joint Research Project titled 'Design of a Scientotext Computational Framework for Retrieval and Contextual Recommendations of High Quality Scholarly Articles' (Grant No. DST/INT/ FRG/DAAD/P-28/2017) for this research work. We also thank Dr Gangan Prathap (National Institute for Interdisciplinary Science and Technology (NIIST), Thiruvananthapuram) and A. P. J. Abdul Kalam Technological University Kerala, for suggestions that significantly improved the manuscript.

Received 8 December 2018; revised accepted 21 January 2019

doi: $10.18520 / \mathrm{cs} / \mathrm{v} 116 / \mathrm{i} / 1304-1313$ 